\title{
A Review of Data Envelopment Analysis in Airline Efficiency: State of the Art and Prospects
}

\author{
Qiang Cui iD and Li-Ting Yu \\ School of Economics and Management, Southeast University, Nanjing 211189, China \\ Correspondence should be addressed to Qiang Cui; cuiqiang1011@163.com
}

Received 17 January 2020; Revised 27 January 2021; Accepted 7 May 2021; Published 19 May 2021

Academic Editor: Rocío de Oña

Copyright ( 2021 Qiang Cui and Li-Ting Yu. This is an open access article distributed under the Creative Commons Attribution License, which permits unrestricted use, distribution, and reproduction in any medium, provided the original work is properly cited.

\begin{abstract}
The rapid development of the aviation industry has brought about the deterioration of the climate, which makes airline efficiency become a hot issue of social concern. As an important nonparametric method, Data Envelopment Analysis (DEA), has been widely applied in efficiency evaluation. This paper examines 130 papers published in the period of 1993-2020 to summarize the literature involving the special application of DEA models in airline efficiency. The paper begins with an overall review of the existing literature, and then the radial DEA, nonradial DEA, network DEA, dynamic DEA, and DEA models with undesirable outputs applied in airline efficiency are introduced. The main advantages and disadvantages of the above models are summarized, and the drivers of airline efficiency are analyzed. Finally, the literature review ends up with future research directions and conclusions.
\end{abstract}

\section{Introduction}

In the past half-century, the airline industry has undergone a lot of changes. On the one hand, from the deregulation and liberalization of the airline industry in the US and Europe to the adoption of "Open Sky" policies in Asia and Latin America, market global competition has greatly stimulated the development of air transportation. According to International Air Transport Association (IATA), the global air transport passenger traffic has grown from about 300 million to 4.5 billion from 1970 to 2019 . Total airline revenue has doubled in the past 20 years, reaching 507 billion dollars in 2019. On the other hand, airlines have been faced with a greater cost challenge and a more complex business environment. The rising fuel prices, labor prices, and the cost of infrastructure together have exerted greater pressure on airlines. It has been reported that the fuel cost and labor cost are the two largest costs of global airlines. In addition, as the competition among airlines has continually intensified, especially after the entry of low-cost airlines, the global airline market structure and competition situation have been changing. At the end of the last century, there were only 3 low-cost carriers (LCC) in the world (Southwest Airline, Ryanair, and Easy Jet), but the number has increased to about 200 now. And the market share of LCC in the global market has reached nearly $30 \%$, which becomes a huge challenge and threat to traditional air carriers. Acquisition, mergers, and alliances among airlines further complicate the airline market environment.

Under this context, boosting operational efficiency has become the key for airlines to survive and develop in the rapidly changing environment. Plenty of scholars have paid much effort in evaluating airline efficiency and have achieved rich results. Among these researches, parametric methods and nonparametric methods are usually applied. Parametric methods mainly involved production function, cost function, and regression analysis, while nonparametric methods are mostly based on Data Envelopment Analysis (DEA). DEA is a method to measure the relative efficiency of a series of multi-input multioutput Decision-Making Units (DMUs) [1]. For decades of studies, DEA models have been rapidly evolved and enriched to adapt to different conditions in various fields. Reference [2] summarized the early studies of DEA models, while [3] provided a detailed review of DEA 
models over the last three decades. With the continuous enrichment of the research results of DEA methods in various fields such as finance, transportation, environment, and education, it is quite necessary to summarize the relevant research results from specific fields. On the one hand, it is helpful to understand the issues that the DEA method mainly solves in related fields. On the other hand, the applicable DEA models can be further extended according to problems in specific fields. Reference [4] examined work of the application of DEA on hospitals and health care. The study in [5] and presented the efficiency studies on rail transport and ports, respectively. The authors of [6-8] investigated the DEA method and its applications in financial services. The study in [9-11] reviewed the application of DEA on energy and environment aspects from different respect.

However, few surveys are available to review systematically the status of studies and to discuss the future research direction of DEA application in the airline industry. As the studies on airlines are enriched and deepen, it is necessary to make a review and summary of relevant researches. Therefore, this paper aims at sorting out the literature of DEA applications in the airline industry, analyzing the research status, and pointing out the possible future research directions. We collect 130 relevant papers over the past 27 years (1993-2020) in the Web of Science (WOS) database and Google Scholar.

The rest of this paper is as follows. Section 2 provides the overall review. Section 3 describes the application of DEA and its extended methods in airline efficiency research. Section 4 presents the future research directions and the conclusions of this study.

\section{Overall Review}

We initially use "airline efficiency" as a keyword to search the studies in the WOS database and Google Scholar. "DEA" and "data envelopment analysis" were applied as keywords to filter the list. After excluding the unrelated papers by reading the abstract of these papers, we got a final sample of 130 papers published from 1993 to 2020.

In recent years, studies on airline efficiency with DEA methods were flourished and active. The annual times cited have reached a sharp growth rate after 2013, which is consistent with the growth in the number of publications. It is not hard to predict that the number will be further increased soon. Figure 1 presents the top 12 journals that 72 of the 130 papers were published in. Among these, the Transportation Research Series (including Part A: Policy and Practice, Part D: Transport and Environment, and Part E: Logistics and Transportation Review) and the Journal of Air Transport Management published most articles, both over 20 ones. Other journals published 2 to 5 papers, respectively.

\section{DEA Models in Airline Efficiency}

3.1. Applications of Radial DEA. Among the papers applying the radial DEA models, there are about 3 classes of methodologies, one is to directly apply the standard CCR or BCC models, and the other is to combine standard DEA models with other methods, especially the combination of parametric and nonparametric methods. And the last is the application of modified or extended DEA models.

In early researches, the traditional radial DEA models including CCR and BCC models were typically employed for evaluating the technical efficiency and scale efficiency of airlines (Table 1). The factors affecting the technical and scale efficiency were further identified.

Initially, when applying DEA models to assess the performance of airlines, financial index, such as total revenue and total cost, was usually selected as the input and output index. The study in [12] considered that it is difficult to assess the performance of international airlines with financial information for the lack of uniformity in statistics across countries. The author proposed adding nonfinancial indexes (such as available ton-kilometers, available seat kilometers, and fleet capacity) as input or output indexes for the DEA approach. Since then, nonfinancial indicators have been extensively developed and popularly applied in the evaluation of airline efficiency with the DEA model.

For a long time, the combination of DEA models and other methods was the most popular way to study airline efficiency. Among the previous researches, the common methods combined with DEA models are (1) regression methodologies, which include Tobit regression [21-23], bootstrapping truncated regression [24, 25], and GLS regression and time-series regression [26, 27]; (2) productivity index, such as Malmquist productivity index [28, 29], Total Productivity Index [30], and Fisher Productivity Index [31]; (3) other methods such as stochastic frontier approach $[32,33]$, free disposal hull $[34,35]$, and balanced scorecard [36]. The detailed ones are shown in Table 2.

Regression methodologies are often used as the second step following the DEA methods to identify the cause of high or low efficiency, through the correlation of efficiency scores and the contextual factors. Productivity indexes, especially the Malmquist productivity index, are frequently applied to attribute the measured change in productivity. Stochastic frontier approach and free disposal hull, which are semiparameter and nonparameter methods, respectively, are usually applied as a complementary contrast or robust examination of the results derived from the DEA method. Reference [36] uniquely combined standard DEA with a balanced scorecard to assess the efficiency by incorporating leading and lagging factors.

With the deepening of research, the traditional DEA models were not suitable for efficiency evaluation in complex situations. Scholars developed a diversity of extended and modified radial DEA models. Among these models, there are mainly the following models: (1) bootstrap DEA models [47-49], (2) DEA models dealing with randomness [13, 50, 51], (3) DEA models with network structures [52-57], (4) dynamic DEA models in consecutive periods [58-61], (5) cross-efficiency DEA models [62]; (6) DEA models distinguishing effective DMUs [61-63], (7) DEA models that deal with undesirable outputs [58], and (8) DEA models dealing with a special type of data existed in inputs and outputs [64]. 


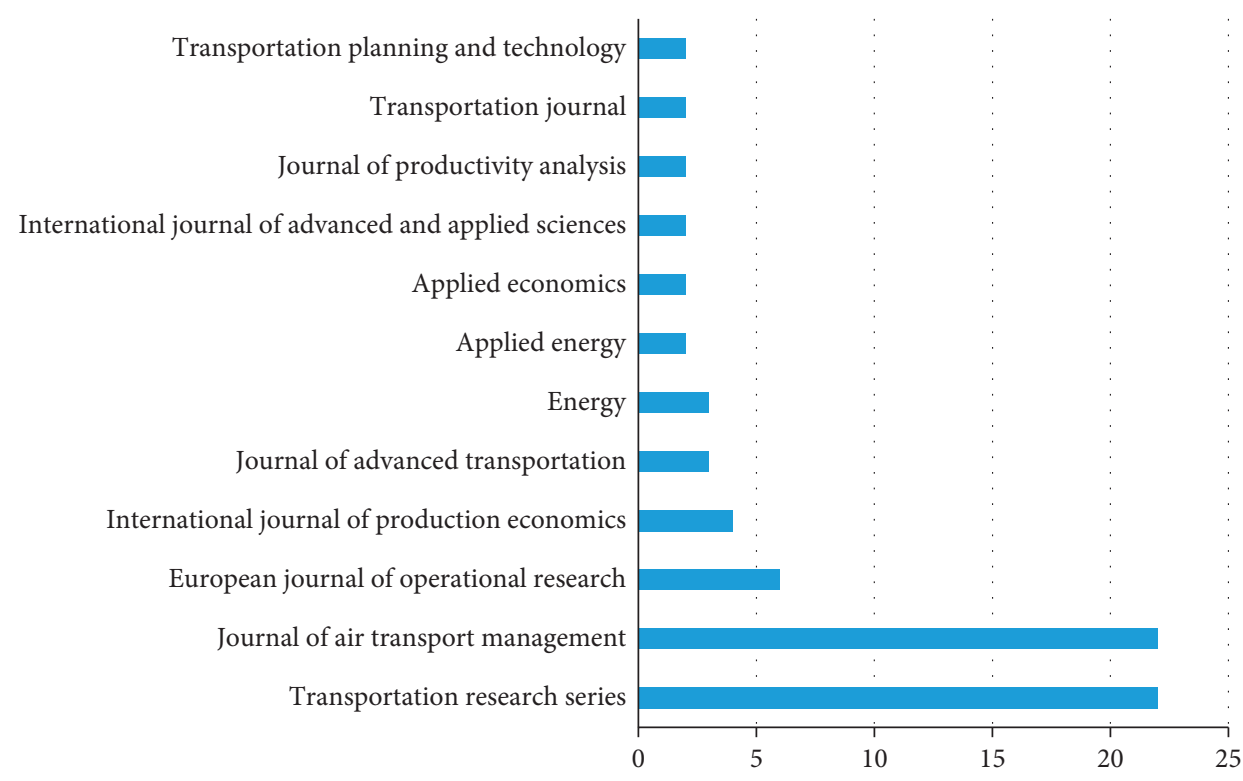

FIGURE 1: Distribution of publication among main journals.

TABLE 1: Application of standard DEA in airline efficiency.

\begin{tabular}{lccc}
\hline Papers & Airlines & Period & Methodology \\
\hline$[12]$ & 15 international airlines & $1989-1992$ & CRS \\
{$[13]$} & 12 major US airlines & $1981-1985$ & VRS \\
{$[14]$} & 53 international airlines & $1993-1997$ & VRS \\
{$[15]$} & 29 international airlines & $1998-2002$ & CRS \\
{$[16]$} & 53 international airlines & 2006 & CRS and VRS \\
{$[17]$} & 30 airlines & 2006 & CRS and VRS \\
{$[18]$} & 66 international airlines & $2007-2009$ & CRS and VRS \\
{$[19]$} & 12 Indian airlines & $2006-2010$ & VRS \\
{$[20]$} & 59 international airlines & 2010 & VRS \\
\hline
\end{tabular}

There is a tendency that the extended DEA models for different situations are integrated to deal with the more complex situations in a deep extension, as shown in Table 3, for example, the network dynamic DEA models and the stochastic network DEA models.

\subsection{Applications of Nonradial DEA and Epsilon-Based} Measure (EBM) Models. Although the radial models have been modified in many papers and are popular in evaluating airline efficiency, it has some shortcomings. Firstly, it neglects the effects of nonradial slacks in the efficiency, which means when an airline's efficiency is 1 but the slacks are not 0 , we cannot identify the airline to be fully effective. When applying the radial model, it is difficult to distinguish a strong effective DMU and a weak effective DMU. Most importantly, radial models assumed that inputs and outputs of DMUs change in the same proportion, but in airline efficiency, inputs such as employees and fuels cannot be substituted completely and may not change proportionally. Therefore, many nonradial models such as slack-based measures and range-adjusted measures have been recently employed in the airline efficiency assessment, as shown in Table 4.
Since the "black box" of airline efficiency has been opened, there is an increasing need to evaluate multistage aviation efficiency, including the overall efficiency and the subefficiency across sectors. Nonradial measures have been popular in network DEA methods. The study in [70] proposed a novel slack-based measure network DEA model (SBM-NDEA) and firstly applied it to airlines efficiency evaluation. They believed that the model represents both the nonstorable feature of transportation service and production technology and can measure the overall efficiency and subefficiency of airlines, even in the presence of shared input. The authors of $[72,73]$ also use SBM-NDEA to evaluate the efficiency of LCC and European airlines. Some papers extended the SBM-NDEA model to Virtual Frontier Network SBM [74]; metadynamic SBM [75]; and network SBM with weak or strong disposability [69, 71, 77]. Apart from the slack-based measure, range-adjusted measure is also introduced into evaluating airline efficiency in recent years $[76,78]$, but the papers are relatively limited. The detailed ones are shown in Table 4.

Since the slacks in these nonradial models may not be necessarily proportional to the inputs or outputs, the projected airlines may lose proportionality in the original inputs or outputs. When evaluating airline efficiency during different years, if the slacks are significantly different, it is difficult to determine the direction of efficiency improvement. Thus, a new model, EBM, proposed by [86] to be a combination of both radial and nonradial models, has been applied in airline efficiency evaluation [80, 81, 85]. It has been also gradually employed in network or dynamic situations.

In addition, these nonradial DEA models have also been combined with other methods such as simple regression analysis, Tobit analysis, and Malmquist-Luenberger index, grey model to explore the factors of airlines efficiency, or the cause of productivity growth. 
TABLE 2: Application of standard DEA combined with other methods in airline efficiency.

\begin{tabular}{|c|c|c|c|}
\hline Papers & Airlines & Period & Methodology \\
\hline$[28]$ & 33 US and European airlines & $1977-1988$ & Standard DEA and Malmquist productivity index \\
\hline [32] & 16 European and US airlinesairlines & $1976-1986$ & Standard DEA and stochastic frontier approach \\
\hline [31] & 21 US airlines & $1983-1984$ & Standard DEA and Fisher Productivity Index \\
\hline [34] & 11 US airlines & $1970-1990$ & DEA and free disposal hull \\
\hline [35] & 11 US airlines & $1970-1990$ & Standard DEA and full disposal hull \\
\hline [37] & 17 European airlines & $1991-1995$ & DEA and Tobit analysis \\
\hline [33] & 16 European airlines & $1977-1990$ & Standard DEA, stochastic frontier approach, and Malmquist productivity index \\
\hline [38] & 38 international airlines & 2000 & Standard DEA and regression analysis \\
\hline [27] & 10 US airlines & $1987-1998$ & Standard DEA and time-series regression \\
\hline [21] & 15 Taiwanese air routes & 2001 & Standard DEA and topic regression \\
\hline [39] & 14 US airlines & 2004 & Superefficiency and CCR \\
\hline [30] & 49 international airlines & 2005 & Standard DEAand TFP \\
\hline [29] & 8 US airlines & 2000-2004 & Standard DEAand Malmquist productivity index \\
\hline [22] & 17 major US airlines & $1999-2008$ & Standard DEA and topic regression \\
\hline [40] & 13 US airlines & 1985-2006 & Standard DEA and topic analysis \\
\hline [24] & 27 European airlines & $2000-2005$ & Standard DEA and bootstrapped truncated regression \\
\hline [23] & 58 international airlines & 2007-2009 & Standard DEA and bootstrapped Tobit \\
\hline [41] & 11 US international airlines & $1992-2008$ & Standard DEA and topic analysis \\
\hline [25] & 18 European PSO airlines & 2007-2009 & Standard DEA and truncated regression analysis \\
\hline [42] & 12 international airlines & $2006-2010$ & Standard DEA and bootstrapped truncated regression \\
\hline [36] & 38 international airlines & 2010 & Standard DEA and balanced scorecard (BSC) \\
\hline [43] & 10 Chinese airlines & $2008-2012$ & Data Envelopment Analysis and Malmquist index \\
\hline [44] & 13 Indian airlines & 2005-2012 & DEA and two-way random-effects GLS regression and Tobit analysis \\
\hline [45] & 15 ASEAN airlines & 2010-2014 & DEA and bootstrapping approaches \\
\hline [46] & 5 ASEAN airlines & $2007-2013$ & DEA-Malmquist and Tobit analysis \\
\hline [26] & 8 African airlines & $2012-2016$ & DEA and a two-way random-effects GLS regression and a Tobit model \\
\hline
\end{tabular}

TABLe 3: Application of extended DEA in airline efficiency.

\begin{tabular}{|c|c|c|c|}
\hline Papers & Airlines & Period & Methodology \\
\hline [13] & 16 US airlines & $1981-1985$ & Maximum likelihood DEA framework \\
\hline [60] & 14 international airlines & $1988-1994$ & Dynamic DEA \\
\hline [51] & 17 European airlines & $1991-1995$ & Stochastic DEA \\
\hline$[65]$ & 7 Canadian airlines & $1960-1999$ & DEA model with adjustment costs and regulatory constraints \\
\hline [57] & 21 US airlines & $2007-2008$ & Two-stage network DEA \\
\hline [53] & 34 Brazilian and American airlines & $1997-2006$ & Two-phase DEA \\
\hline [54] & 15 US airlines & $2006-2008$ & Network DEA and two-dimensional efficiency decomposition \\
\hline$[55]$ & 30 US airlines & 2010 & Two-stage network DEA \\
\hline$[66]$ & 12 US airlines & $2008-2011$ & Service quality-adjusted DEA and Mann-Whitney test \\
\hline [67] & 10 US airlines & $1998-2010$ & B-convex DEA model \\
\hline$[68]$ & 7 Chinese airlines & 2011 & Nonarchimedes dimensionless CCR \\
\hline [47] & 48 international airlines & $2007-2010$ & Bootstrapped DEA \\
\hline [49] & 42 US and European airlines & $2001-2005$ & Bootstrapped DEA and bootstrapped truncated regression \\
\hline [56] & 27 US airlines & 2012 & Three-stage unoriented network DEA \\
\hline$[62]$ & 11 international airlines & $2008-2012$ & Virtual frontier benevolent DEA cross-efficiency model \\
\hline [61] & 19 Latin American airlines & $2010-2014$ & $\begin{array}{l}\text { A two-stage approach combining virtual frontier dynamic DEA and simplex } \\
\text { regression }\end{array}$ \\
\hline [69] & 18 international airlines & $2008-2014$ & Dynamic environmental DEA \\
\hline [52] & 87 European airlines & $2000-2010$ & Network DEA \\
\hline [59] & 8 Iranian airlines & $2010-2012$ & Dynamic network DEA \\
\hline$[50]$ & 13 international airlines & $2006-2014$ & Stochastic network DEA (SNDEA) \\
\hline$[48]$ & 14 international airlines & $2006-2015$ & Bootstrapping DEA and double bootstrap regression \\
\hline$[63]$ & 30 international airlines & $2012-2016$ & DEA with superefficiency and intertemporal approach \\
\hline$[64]$ & 7 Iranian airlines & $2010-2012$ & Dynamic network DEA with fuzzy inputs and outputs \\
\hline
\end{tabular}

3.3. Network DEA in Airline Efficiency. Before the application of network DEA, each airline was treated unit with multiple inputs and outputs, and the evaluation of airline efficiency was limited to the overall efficiency, which did not reveal the internal relations inside the "black box." Network DEA models break down the system into multiple processes and divisions, taking into consideration the component processes and the relations between them via intermediate 
TABLE 4: Application of nonradial DEA and EBM in airline efficiency.

\begin{tabular}{lccc}
\hline Papers & Airlines & Period & Methodology \\
\hline$[70]$ & 11 middle eastern airlines & 2010 & Slack-based measure (SBM) network DEA \\
{$[71]$} & 27 international airlines & 2010 & Slack-based environmental measure (SBM) DEA \\
[72] & 16 lost cost carriers & 2008 & Slack-based measure (SBM) network DEA \\
{$[73]$} & Two-stage slack-based measure (SBM) \\
{$[74]$} & 22 international airlines & $2008-2012$ & Virtual frontier network SBM \\
{$[75]$} & 35 international airlines & $2007-2009$ & Metadynamic network slack-based measure (MDN-SBM) \\
{$[69]$} & 22 international airlines & $2008-2012$ & Network SBM with weak disposability \\
{$[76]$} & 22 international airlines & $2008-2012$ & Virtual frontier dynamic range-adjusted measure \\
{$[77]$} & 22 international airlines & $2008-2012$ & Network SBM with weak disposability and strong disposability \\
{$[78]$} & 7 Iranian airlines & $2007-2011$ & Range-adjusted measure and strong complementary slackness condition and \\
{$[79]$} & 13 international airlines & 2010 & discriminant analysis \\
{$[80]$} & 19 international airlines & $2008-2014$ & Network Epsilon-based and slack-based measure and regression analysis \\
{$[81]$} & 19 international airlines & $2009-2014$ & Dynamic Epsilon-based measure \\
{$[82]$} & 18 Chinese and the US airlines & $2011-2014$ & Slack-based measure and Tobit analysis and Malmquist-Luenberger index \\
{$[83]$} & 30 international airlines & $2009-2012$ & Two-stage dynamic network SBM-DEA \\
{$[84]$} & 11 ASEAN airlines & $2013-2016$ & Grey model and SBM-DEA \\
{$[85]$} & 29 international airlines & $2021 \mathrm{e}-2023 \mathrm{e}$ & Network Epsilon-based measure with managerial disposability \\
\hline
\end{tabular}

products. Different systems have different structures, which are mainly classified into the series structure, parallel structure, and series-parallel structure. In the application for the airline industry, the series structure was the most popular and suitable network model, as shown in Table 5. Regarding series structure, some papers considered the airline system a two-stage process, which usually comprises productivity process and consumption process, calculating the technical efficiency and marketing efficiency, respectively; some studies broke down the system into three stages, usually consisting of operation stage, service stage, and sales stage. A few studies divided the airline system into several parallel divisions, such as passenger subproduction and cargo subproduction in [70] and operating stage and fleet maintenance stage in [80]. Figures 2 and 3 illustrate the two divisions and two-stage series-parallel structure in [70] and Figure 3 presents the three-stage series structure in [91].

For the inputs and outputs, most papers assumed that the intermediate products produced in the former process would be consumed by the next process. However, some studies have considered the final (usually undesirable) outputs produced in the intermedia stages, such as the delays in [50], the greenhouse gases in [77], and the carbon dioxide in [69]. The exogenous inputs for the second stage or third stage have also been taken into account in many papers, such as the selling cost $[73,74,77]$; the fleet size and destination $[56,74,77,80]$; and the abatement expense in [69]. In addition, as the allocation of shared inputs in different divisions and stages, a few studies took into account the shared inputs such as the number of employees in [70] and in $[70,91]$ took the number of employees as a shared input for different parallel divisions (Figure 4), while [91] assumed the number of employees (NE) as a shared input for different stages (Figure 2). In Figure 2, NE is the number of employees, AK is aviation kerosene, FS is fleet size, SC is sales cost, and TR is total revenue.

It should be noted that most researchers paid attention to the mainstream process which eventually produces revenue and took the undesirable outputs as additional outputs. Reference [69] focused on the carbon abatement process of airlines, taking the RPK and RTK as additional desirable outputs.

3.4. Dynamic DEA in Airline Efficiency. In this section, we will introduce the application of dynamic DEA models as well as dynamic network DEA models in airline efficiency. Although there were plenty of previous studies evaluating intertemporal performance of airlines in the application of Malmquist productivity index or window analysis, they ignored the transition elements existing in airline operations. For example, the fleets and capital stock of an airline can be carried over from one period to another. In order to model the intertemporal features of these transition elements, scholars have established many dynamic DEA models considering the carryover, including the basic dynamic DEA model in [92]; the dynamic SBM model in [93]; the dynamic network DEA in [94]; the dynamic multiactivity network DEA in [95]; and the dynamic network SBM in [86].

Currently, dynamic DEA models applied in airline efficiency involved dynamic SBM [96]; virtual frontier dynamic SBM [58]; virtual frontier dynamic range-adjusted measure [61, 76]; dynamic environmental DEA [58, 85, 97]; dynamic EBM [81]. Some papers combined dynamic models with network models, which included the relational dynamic network standard DEA model [59]; metadynamic network slack-based measure [75]; dynamic network SBM [83]; and fuzzy dynamic network DEA [64]. The detailed ones can be found in Table 6.

As for the carryover activities, opinions varied in the carryover element selection. For papers that did not take network structure into consideration, dynamic factors like capital stock, fleet size, stockholder equity liabilities, and intangible assets were assumed as carryovers, that is, the outputs of the whole process in the previous term and the 
TABle 5: Details of literature with network DEA.

\begin{tabular}{|c|c|c|c|c|}
\hline Papers & Stages & Inputs and outputs of the 1st stage & $\begin{array}{l}\text { Inputs and outputs of the } \\
\text { 2nd stage }\end{array}$ & $\begin{array}{l}\text { Inputs and } \\
\text { outputs of the } \\
\text { 3rd stage }\end{array}$ \\
\hline$[21]$ & $\begin{array}{l}\text { Two stages: cost efficiency and } \\
\text { service effectiveness }\end{array}$ & $\begin{array}{c}\text { Inputs: fuel cost, personnel cost, and } \\
\text { aircraft cost } \\
\text { Outputs: number of flights and seat miles }\end{array}$ & $\begin{array}{l}\text { Inputs: number of flights } \\
\text { and seat miles } \\
\text { Outputs: passenger miles } \\
\text { and embarkation } \\
\text { passengers }\end{array}$ & \\
\hline$[57]$ & Two stages & $\begin{array}{c}\text { Inputs: cost per ASM, salaries per ASM, } \\
\text { wages per ASM, benefits per ASM, and fuel } \\
\text { expense per ASM } \\
\text { Outputs: Load factor and fleet size }\end{array}$ & $\begin{array}{c}\text { Inputs: load factor and } \\
\text { fleet size } \\
\text { Outputs: RPM }\end{array}$ & \\
\hline$[53]$ & $\begin{array}{l}\text { Two phases: operational } \\
\text { performance and financial } \\
\text { performance }\end{array}$ & $\begin{array}{c}\text { Inputs: aircraft fuel, wages, salaries and } \\
\text { benefits, and cost per ASM } \\
\text { Outputs: RPK }\end{array}$ & $\begin{array}{l}\text { Inputs: the inverse of } \\
\text { efficiency in phase } 1 \\
\text { Outputs: flight revenue } \\
\text { and flight income }\end{array}$ & \\
\hline$[55]$ & $\begin{array}{l}\text { Two stages: production } \\
\text { efficiency and marketing } \\
\text { efficiency }\end{array}$ & $\begin{array}{l}\text { Inputs: number of employees, fuel } \\
\text { consumption, total number of seats, cost of } \\
\text { flight equipment, maintenance expenses, } \\
\text { and cost of equipment and property } \\
\text { Outputs: ASM and ATM }\end{array}$ & $\begin{array}{l}\text { Inputs: ASM and ATM } \\
\text { Outputs: RPM and } \\
\text { nonpassenger revenue }\end{array}$ & \\
\hline$[70]$ & $\begin{array}{l}\text { Two stages: technical efficiency } \\
\text { and service effectiveness }\end{array}$ & $\begin{array}{l}\text { Inputs: number of passenger planes, } \\
\text { number of employees, and number of } \\
\text { cargo planes } \\
\text { Outputs: passenger-plane-km and cargo- } \\
\text { plane-km }\end{array}$ & $\begin{array}{l}\text { Inputs: passenger-plane- } \\
\text { km and cargo-plane-km } \\
\text { Outputs: passenger-km } \\
\text { and ton-km; }\end{array}$ & \\
\hline [73] & $\begin{array}{l}\text { Two stages: production } \\
\text { process and sales process }\end{array}$ & $\begin{array}{l}\text { Inputs: fuel cost, noncurrent assets, wages } \\
\text { and salaries, and other operating costs } \\
\text { Outputs: ASK and ATK }\end{array}$ & $\begin{array}{l}\text { Inputs: ASK, ATK, and } \\
\text { selling costs } \\
\text { Outputs: RPK and RTK }\end{array}$ & \\
\hline$[72]$ & $\begin{array}{l}\text { Two stages: production } \\
\text { process and consumption } \\
\text { process }\end{array}$ & $\begin{array}{c}\text { Inputs: employee, fuel, and fleet } \\
\text { Outputs: seat-mile and destination- } \\
\text { adjusted GDP }\end{array}$ & $\begin{array}{l}\text { Inputs: seat-mile and } \\
\text { destination-adjusted } \\
\text { GDP } \\
\text { Outputs: pass-mile }\end{array}$ & \\
\hline$[56]$ & $\begin{array}{l}\text { Three stages: operations stage, } \\
\text { services stage, and sales stage }\end{array}$ & $\begin{array}{c}\text { Inputs: operating expenses } \\
\text { Outputs: ASK }\end{array}$ & $\begin{array}{l}\text { Inputs: ASK, fleet size, } \\
\text { and destinations } \\
\text { Outputs: RPM }\end{array}$ & $\begin{array}{l}\text { Inputs: RPM } \\
\text { Outputs: } \\
\text { operating } \\
\text { revenue }\end{array}$ \\
\hline$[74]$ & $\begin{array}{l}\text { Three stages: operations stage, } \\
\text { services stage, and sales stage }\end{array}$ & $\begin{array}{c}\text { Inputs: number of employees and aviation } \\
\text { kerosene } \\
\text { Outputs: ATK and ASK }\end{array}$ & $\begin{array}{l}\text { Inputs: ATK, ASK, and } \\
\text { fleet size } \\
\text { Outputs: RTK and RPK }\end{array}$ & $\begin{array}{l}\text { Inputs: RTK, } \\
\text { RPK, and sales } \\
\text { costs } \\
\text { Outputs: total } \\
\text { business income }\end{array}$ \\
\hline$[77,87,88]$ & $\begin{array}{l}\text { Three stages: operations stage, } \\
\text { services stage, and sales stage }\end{array}$ & $\begin{array}{c}\text { Inputs: number of employees and aviation } \\
\text { kerosene } \\
\text { Outputs: ATK and ASK }\end{array}$ & $\begin{array}{l}\text { Inputs: ATK, ASK, and } \\
\text { fleet size; } \\
\text { Outputs: RTK, RPK, and } \\
\text { greenhouse gases }\end{array}$ & $\begin{array}{l}\text { Inputs: RTK, } \\
\text { RPK, and sales } \\
\text { costs } \\
\text { Outputs: total } \\
\text { business income }\end{array}$ \\
\hline [69] & $\begin{array}{l}\text { Two stages: operations stage } \\
\text { and carbon abatement stage }\end{array}$ & $\begin{array}{c}\text { Inputs: salaries, wages and benefits, fuel } \\
\text { expenses, and total assets } \\
\text { Outputs: RPK, RTK, and estimated carbon } \\
\text { dioxide }\end{array}$ & $\begin{array}{c}\text { Inputs: estimated carbon } \\
\text { dioxide and abatement } \\
\text { expense } \\
\text { Outputs: carbon dioxide }\end{array}$ & \\
\hline$[52]$ & $\begin{array}{l}\text { Two stages: intermediate } \\
\text { efficiency and final efficiency }\end{array}$ & $\begin{array}{c}\text { Inputs: capital, labor, and materials } \\
\text { Outputs: RTK/load factor }\end{array}$ & $\begin{array}{l}\text { Inputs: RTK/load factor } \\
\text { Outputs: revenue ton- } \\
\text { kilometers }\end{array}$ & \\
\hline [80] & $\begin{array}{l}\text { Four stages: operating stage, } \\
\text { fleet maintenance stage, } \\
\text { services stage, and sales stage }\end{array}$ & $\begin{array}{c}\text { Inputs: number of employees and aviation } \\
\text { kerosene } \\
\text { Outputs: ASK and ATK } \\
\text { Inputs: maintenance costs } \\
\text { Outputs: fleet size }\end{array}$ & $\begin{array}{l}\text { Inputs: ASK, ATK, fleet } \\
\text { size, and number of } \\
\text { destinations } \\
\text { Outputs: RPK and RTK }\end{array}$ & $\begin{array}{l}\text { Inputs: RPK, } \\
\text { RTK, and sales } \\
\text { cost } \\
\text { Outputs: total } \\
\text { business income }\end{array}$ \\
\hline
\end{tabular}


TABLE 5: Continued.

\begin{tabular}{|c|c|c|c|c|}
\hline Papers & Stages & Inputs and outputs of the 1st stage & $\begin{array}{l}\text { Inputs and outputs of the } \\
\text { 2nd stage }\end{array}$ & $\begin{array}{l}\text { Inputs and } \\
\text { outputs of the } \\
\text { 3rd stage }\end{array}$ \\
\hline [50] & $\begin{array}{l}\text { Two stages: network efficiency } \\
\text { and flight efficiency }\end{array}$ & $\begin{array}{l}\text { Inputs: fuel, number of plants, and number } \\
\text { of employees } \\
\text { Outputs: number of landings and delays }\end{array}$ & $\begin{array}{c}\text { Inputs: number of } \\
\text { landings } \\
\text { Outputs: } \mathrm{CO}_{2} \text {, cargo, and } \\
\text { number of passengers }\end{array}$ & \\
\hline$[81,85,89,90]$ & $\begin{array}{l}\text { Three stages: operations stage, } \\
\text { services stage, and sales stage }\end{array}$ & $\begin{array}{c}\text { Inputs: operating expenses } \\
\text { Outputs: ASK }\end{array}$ & $\begin{array}{l}\text { Inputs: ASK and fleet } \\
\text { size } \\
\text { Outputs: RPK and } \\
\text { greenhouse gases }\end{array}$ & $\begin{array}{l}\text { Inputs: RPK and } \\
\text { sales costs } \\
\text { Outputs: total } \\
\text { business income }\end{array}$ \\
\hline
\end{tabular}

Notes: ASM, available seat miles; RPM, revenue passenger miles; ATM, available ton-miles; ASK, available seat kilometers; ATK, available ton-kilometers; RPK, revenue passenger kilometers; RTK, revenue ton-kilometers.

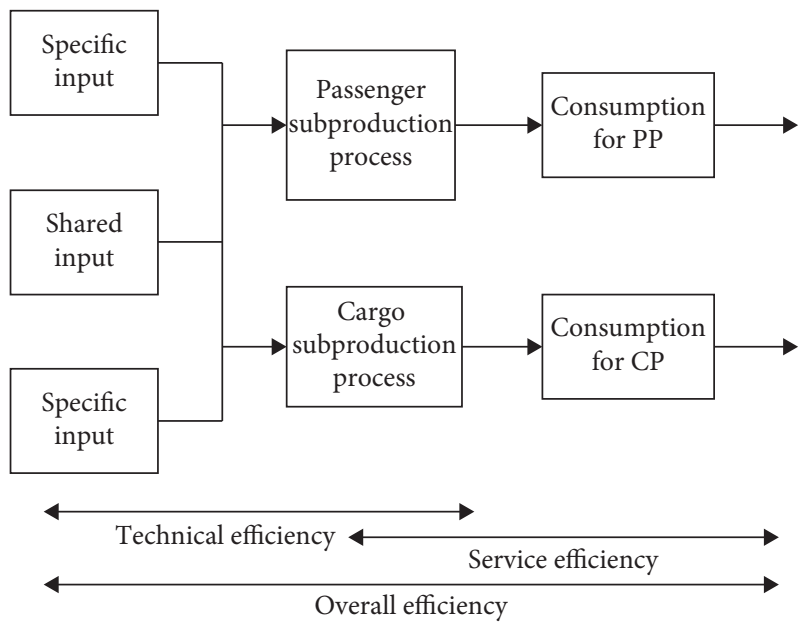

FIgURE 2: Three-stage series structure in [90].

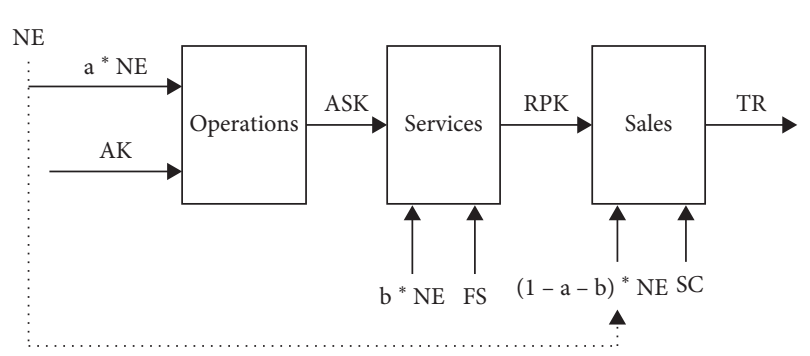

Figure 3: Dynamic structure in [58].

inputs of the whole process in the subsequent period $[58,61,76,81,97,99-101]$.

For papers combining dynamic and network models, the selected carryovers are different in substages. The study in [75] selected net revenues and accident occurrence as desirable and undesirable carryovers, respectively, to the consumption division between consecutive periods. The authors of $[59,64]$ also assumed that carry activities existed in consumption division and selected the number of fleet seats as a carryover. The study in [83] considered a self-owned fleet as a carryover to production division and waypoints as a carryover to service division in consecutive terms. Figures 3 and 5 present the dynamic structure in [58] and the dynamic

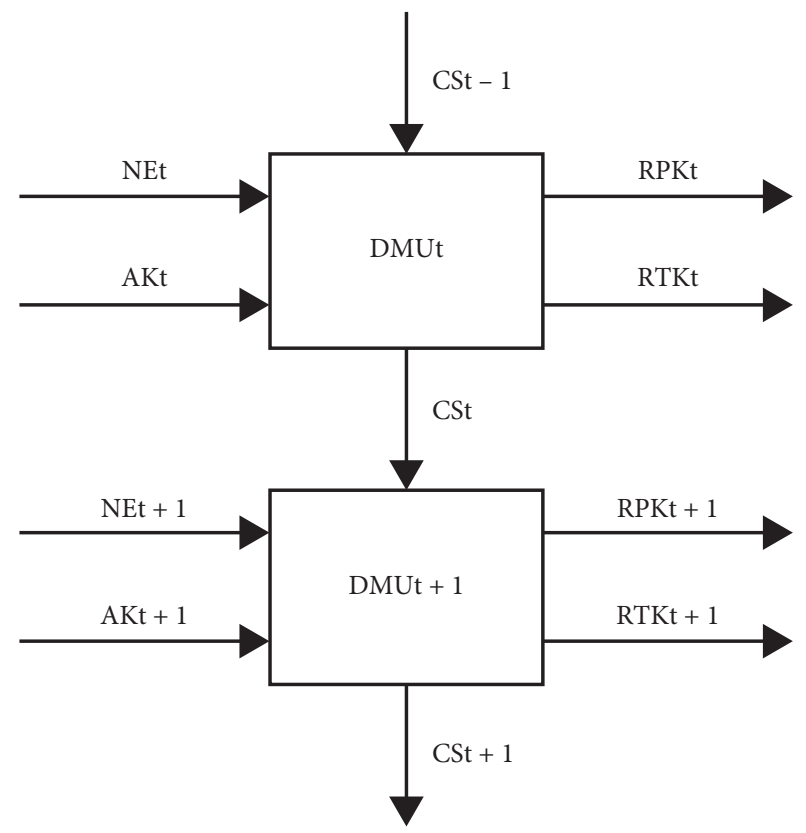

FIgURE 4: Two-stage series-parallel structure in [70].

network structure in [83], respectively. In Figure 3, NE is the number of employees, AK is aviation kerosene, and CS is capital stock. In Figure 5, ASK is available seat kilometers, and FATK is freight available ton-kilometers.

3.5. DEA Models considering Undesirable Outputs. When assessing the efficiency of airlines, it is necessary to consider the generation of undesirable outputs in the DEA models. According to [9], there are about five approaches in modeling pollution-generating technologies at present: (1) Free disposability (strong disposability), an approach to treat undesirable outputs as free disposable inputs for the argument that the environment capacity is strong enough to dispose of bad outputs of environmentally detrimental products. (2) Weak disposability, in which the reduction of undesirable outputs requires a proportional reduction of desirable outputs. (3) Byproduction model. In this model, the inputs producing undesirable outputs are separated from the ones producing desirable outputs, and the two sets of efficiency scores are 
TABLe 6: Details of literature with dynamic DEA.

\begin{tabular}{lccc}
\hline Papers & Period & Carryover (dynamic factor) & Samples \\
\hline$[60]$ & $1988-1994$ & Capital & 14 international airlines \\
{$[75]$} & $2007-2009$ & Net revenue & 35 international airlines \\
{$[59]$} & $2010-2012$ & The number of fleet seats & 8 Iranian airlines \\
{$[61]$} & $2010-2014$ & The number of planes & 19 Latin American airlines \\
{$[76]$} & Capital stock & 22 international airlines \\
{$[58]$} & $2008-2012$ & Capital stock & 21 international airlines \\
{$[97]$} & $2008-2012$ & Capital stock & 18 international airlines \\
{$[81]$} & $2008-2014$ & Capital stock & 19 international airlines \\
{$[96]$} & $2009-2014$ & Stockholder equity liabilities; intangible asserts & 25 international airlines \\
{$[83]$} & $2008-2013$ & Size of self-owned fleet waypoints & 30 international airlines \\
{$[98]$} & $2009-2012$ & Fleet size & 29 international airlines \\
{$[64]$} & $2021-2023$ & The number of fleet seats & 7 Iranian airlines \\
{$[85]$} & $2010-2012$ & Capital stock & 18 international airlines \\
{$[99]$} & $2008-2014$ & Fleet size & 29 international airlines \\
\hline
\end{tabular}

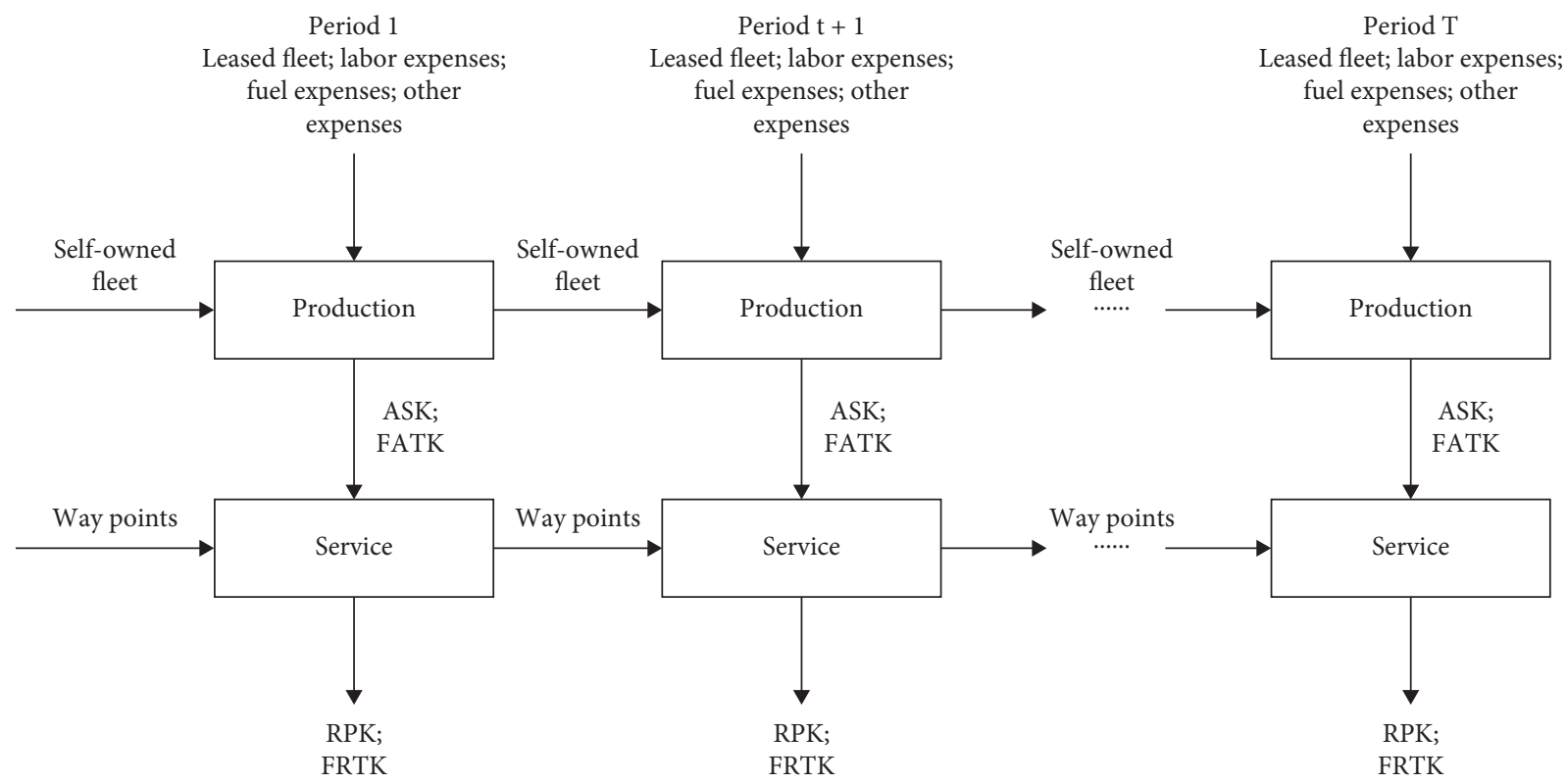

Figure 5: Dynamic network structure in [83].

averaged. (4) Weak G-disposability. With direction vectors included in the model, it indicates that with more inputs it is possible to produce less desirable output and more undesirable outputs. (5) Natural disposability and managerial disposability. Natural disposability is equal to free disposability, while managerial disposability treats inputs as outputs and the undesirable outputs are modeled as inputs.

Papers with these models employed in airline efficiency evaluation are limited at present. When considering the environmental efficiency of airlines, the Virtual Frontier Benevolent DEA Cross-Efficiency model [62]; Benevolent DEA cross PAC (Pollution Abatement Costs) model [102]; network SBM with weak disposability [69]; network SBM with weak disposability and with strong disposability [77]; RAM with weak disposability and with strong disposability [103]; Virtual Frontier Network RAM models with weak disposability [88]; network EBM with managerial disposability [85]; dynamic RAM with unified natural and managerial disposability [99] have been established to evaluate the energy efficiency of airlines. Among these researches, it was found that the model with weak disposability is more reasonable in distinguishing efficiency differences and confirming benchmarking airlines, while strong disposability is a more reasonable way in treating undesirable outputs. Further, under natural disposability, the indices related to undesirable output have a larger role in deciding benchmarking airlines.

On the other hand, with the increasing attention to the emissions control costs, there is a tendency to focus on the impact of environmental pressure on PAC. The study in [85] defined the pollution abatement cost as the ratio of the outputs when the undesirable outputs are freely disposed to the outputs when the undesirable outputs are weakly disposed of. This novel definition which utilized the two approaches modeling undesirable outputs can express the output loss of different disposability modes of undesirable outputs 
reasonably. The study in [102] applied a DEA cross PAC model to discuss the impact of cooperation on airline's PAC.

\section{Conclusions and Future Research Directions}

4.1. Conclusions. This paper reviews the application of DEA methods in airline efficiency with 130 articles in high-impact journals as samples. The DEA models mainly consist of radial and nonradial models. For radial models, the standard CCR and BCC models, a combination of standard DEA and other methods, and extended and modified models are widely used in airline efficiency studies. For nonradial models, SBM and RAM models are popularly applied. In addition, the EBM model that unifies the features of radial and nonradial measures has been gradually employed in airline efficiency evaluation. In recent years, there is a trend that DEA models considering network structure and dynamic situation are constructed; with the increasing importance of environmental efficiency, approaches dealing with undesired outputs also arouse attention.

From the existing research results, we can know that the airline efficiencies are different for different periods and regions, different types of airlines, and different substages. But overall, the productivity of the international airline industry has been largely improved over the past 30 years, and the operational efficiency of airlines had tended to converge. Drivers of airline efficiency are from the firm level, industry level, and macroenvironment level, but there are slight differences in the results of these studies.

This review does not include airline efficiency papers using parametric methods and those investigating the efficiency of airports. We will expand the range of papers in the future.

4.2. Future Research Directions. According to the review and combing of previous literature, we found that DEA and airline efficiency have the following main research directions in the future:

Firstly, with respect to DEA models applied in airline efficiency, although numerous different DEA models have been developed and applied, there are also many DEA models that deal with more complex problems and tricky data that needed to be established. For example, models dealing with special types of data (such as ordinal data, negative data, and interval data) have not been applied in airline efficiency yet. But in practice, there are some special circumstances. For example, when airline profit is used as an indicator, it may be a negative value. Furthermore, sometimes the data may be an interval data rather than an exact value. Furthermore, with most airlines facing challenges from rising fuel prices and stricter environmental regulations, airline cooperation and alliance will become the trend. The application of DEA models considering airline competition and cooperation should be another important future topic.
In addition, radial and nonradial DEA models have been widely used in airline efficiency evaluation, but the application of EBM is still limited. Since the EBM model combines the feature of radial and nonradial measures to a unified framework, the extended DEA models based on EBM will be expected in the future.

Secondly, regarding DEA network structure and dynamic structure applied in airline efficiency, there is room for further exploration. Apart from the production, service, and sales process, is there any other stage in the process of airline efficiency? And are there any other final outputs and independent or shared inputs at different stages that have not been considered? Upon dynamic DEA models, there are about three future research directions. First, since previous studies mostly took the past time periods as sample periods, it will be valuable and innovative if we can take advantage of other data prediction methodologies and dynamic DEA models to predict airline efficiency in the future time periods. Second, the carryovers found in previous literature are still limited (usually capital stock and fleet size). More transition elements that better reflect the dynamic efficiency of airlines need to be explored. Finally, the dynamic network DEA models with a longer time and more stages can be tried in airline efficiency research, which allows for a better exploration of the drivers of airline efficiency.

Thirdly, regarding the approaches considering undesirable outputs, only the free disposability, weak disposability, and managerial disposability approaches have been applied in the environmental efficiency evaluation of airlines, lacking the application of other pollution modeling approaches. What is more, since there is a tendency that the integrated DEA models will be more suitable for handling complex situations, the dynamic network DEA with approaches handling special types of data and with different pollution modeling approaches are needed in future research.

Fourthly, apart from the model innovation and extension, there are several future research directions regarding the efficiency evaluation of airlines and the efficiency drivers. For example, the economic efficiency of airlines has been given much focus, but the social and safety efficiency of airlines have been paid much less attention. Since the development of airlines has a great impact on society, the related efficiency measurement will also be a hot research direction in the future. Therefore, it can be more concerned with the noneconomic efficiency of airlines such as safety efficiency and carbon abatement efficiency.

Fifthly, among the factors affecting airline efficiency, there is little research paying attention to the industry and macroenvironmental level factors. At present, most research focuses on the measurement and exploration of specific airline efficiency, which cannot assess impact in the context of the industry. As the pressure of environmental policies increases, it is necessary to further 
reveal the connection between environmental policies and airline efficiency, to answer questions like what is the impact of environmental policies on airline efficiency and how does it affect.

\section{Data Availability}

The data used to support the findings of this study are available from the corresponding author upon request.

\section{Conflicts of Interest}

The authors declare no conflicts of interest.

\section{Acknowledgments}

This research was funded by the National Natural Science Foundation of China (nos. 71403034 and 71701088).

\section{References}

[1] A. Charnes, W. W. Cooper, and E. Rhodes, "Measuring the efficiency of decision making units," European Journal of Operational Research, vol. 2, no. 6, pp. 429-444, 1978.

[2] L. M. Seiford and R. M. Thrall, "Recent developments in DEA: the mathematical programming approach to frontier analysis," Journal of Econometrics, vol. 46, no. 1-2, pp. 7-38, 1990.

[3] W. D. Cook and L. M. Seiford, "Data envelopment analysis (DEA) - thirty years on," European Journal of Operational Research, vol. 192, no. 1, pp. 1-17, 2009.

[4] B. Hollingsworth, P. J. Dawson, and N. Maniadakis, "Efficiency measurement of health care: a review of non- parametric methods and applications," Health Care Management Science, vol. 2, no. 3, pp. 161-172, 1999.

[5] T. H. Oum, W. G. Waters, and C. Yu, "A survey of productivity and efficiency measurement in rail transport," Journal of Transport Economics and Policy, vol. 33, no. 1, pp. 9-42, 1999.

[6] S. Kaffash and M. Marra, "Data envelopment analysis in financial services: a citations network analysis of banks, insurance companies and money market funds," Annals of Operations Research, vol. 253, no. 1, pp. 307-344, 2017.

[7] J. C. Paradi and H. Zhu, "A survey on bank branch efficiency and performance research with data envelopment analysis," Omega, vol. 41, no. 1, pp. 61-79, 2013.

[8] E. Thanassoulis, "Data envelopment analysis and its use in banking," Interfaces, vol. 29, no. 3, pp. 1-13, 1999.

[9] K. H. Dakpo, P. Jeanneaux, and L. Latruffe, "Modelling pollution-generating technologies in performance benchmarking: recent developments, limits and future prospects in the nonparametric framework," European Journal of Operational Research, vol. 250, no. 2, pp. 347-359, 2016.

[10] P. Zhou, B. W. Ang, and K. L. Poh, "Measuring environmental performance under different environmental DEA technologies," Energy Economics, vol. 30, no. 1, pp. 1-14, 2008.

[11] H. Zhou, Y. Yang, Y. Chen, and J. Zhu, "Data envelopment analysis application in sustainability: the origins, development and future directions," European Journal of Operational Research, vol. 264, no. 1, 2018.
[12] M. Schefczyk, "Operational performance of airlines: an extension of traditional measurement paradigms," Strategic Management Journal, vol. 14, no. 4, pp. 301-317, 1993.

[13] R. D. Banker and H. H. Johnston, "Evaluating the impacts of operating strategies on efficiency in the US airline industry," in Data Envelopment Analysis: Theory, Methodology, and Applications, pp. 97-128, Springer, Dordrecht, Dutch, 1994.

[14] H. M. P. Capobianco and E. Fernandes, "Capital structure in the world airline industry," Transportation Research Part A: Policy and Practice, vol. 38, no. 6, pp. 421-434, 2004.

[15] S. Hong and A. Zhang, "An efficiency study of airlines and air cargo/passenger divisions: a DEA approach,” World Review of Intermodal Transportation Research, vol. 3, no. 1-2, pp. 137-149, 2010.

[16] B. L. Lee and A. C. Worthington, "The relative efficiency of international, domestic, and budget airlines: nonparametric evidence," Discussion Papers in Economics, 2010.

[17] W. K. Wang, W. M. Lu, and C. J. Tsai, "The relationship between airline performance and corporate governance amongst US listed companies," Journal of Air Transport Management, vol. 17, no. 2, pp. 148-152, 2011.

[18] R. Merkert and P. S. Morrell, "Mergers and acquisitions in aviation-management and economic perspectives on the size of airlines," Transportation Research Part E: Logistics and Transportation Review, vol. 48, no. 4, pp. 853-862, 2012.

[19] R. K. Jain and R. Natarajan, "A DEA study of airlines in India," Asia Pacific Management Review, vol. 20, no. 4, pp. 285-292, 2015.

[20] H. Min and S. J. Joo, "A comparative performance analysis of airline strategic alliances using data envelopment analysis," Journal of Air Transport Management, vol. 52, pp. 99-110, 2016.

[21] Y.-C. Chiou and Y.-H. Chen, "Route-based performance evaluation of Taiwanese domestic airlines using data envelopment analysis," Transportation Research Part E: Logistics and Transportation Review, vol. 42, no. 2, pp. 116-127, 2006.

[22] M. Greer, "Is it the labor unions' fault? dissecting the causes of the impaired technical efficiencies of the legacy carriers in the United States," Transportation Research Part A: Policy and Practice, vol. 43, no. 9-10, pp. 779-789, 2009.

[23] R. Merkert and D. A. Hensher, "The impact of strategic management and fleet planning on airline efficiency-a random effects tobit model based on DEA efficiency scores," Transportation Research Part A: Policy and Practice, vol. 45, no. 7, pp. 686-695, 2011.

[24] C. P. Barros and N. Peypoch, "An evaluation of European airlines' operational performance," International Journal of Production Economics, vol. 122, no. 2, pp. 525-533, 2009.

[25] R. Merkert and G. Williams, "Determinants of European PSO airline efficiency-evidence from a semi-parametric approach," Journal of Air Transport Management, vol. 29, pp. 11-16, 2013.

[26] O. Mhlanga, J. Steyn, and J. Spencer, "The airline industry in south Africa: drivers of operational efficiency and impacts," Tourism Review, vol. 73, no. 3, pp. 389-400, 2018.

[27] N. Tsikriktsis and J. Heineke, "The impact of process variation on customer dissatisfaction: evidence from the US domestic airline industry," Decision Sciences, vol. 35 , no. 1, pp. 129-141, 2004.

[28] V. Distexhe and S. Perelman, "Technical efficiency and productivity growth in an era of deregulation: the case of airlines," Swiss Journal of Economics and Statistics, vol. 130, no. 4, pp. 669-689, 1994. 
[29] M. R. Greer, "Nothing focuses the mind on productivity quite like the fear of liquidation: changes in airline productivity in the United States, 2000-2004," Transportation Research Part A: Policy and Practice, vol. 42, no. 2, pp. 414-426, 2008.

[30] C. Barbot, Á. Costa, and E. Sochirca, "Airlines performance in the new market context: a comparative productivity and efficiency analysis," Journal of Air Transport Management, vol. 14, no. 5, pp. 270-274, 2008.

[31] S. C. Ray and K. Mukherjee, "Decomposition of the fisher ideal index of productivity: a non-parametric dual analysis of us airlines data," Economic Journal, vol. 106, no. 439, pp. 1659-1678, 1996.

[32] D. H. Good, L.-H. Röller, and R. C. Sickles, “Airline efficiency differences between Europe and the US: implications for the pace of EC integration and domestic regulation," European Journal of Operational Research, vol. 80, no. 3, pp. 508-518, 1995.

[33] R. C. Sickles, D. H. Good, and L. Getachew, "Specification of distance functions using semi-and nonparametric methods with an application to the dynamic performance of eastern and western European air carriers," Journal of Productivity Analysis, vol. 17, no. 1-2, pp. 133-155, 2002.

[34] I. M. S. Alam and R. C. Sickles, "The relationship between stock market returns and technical efficiency innovations; evidence from the US airline industry," Journal of Productivity Analysis, vol. 9, no. 1, pp. 35-51, 1998.

[35] I. M. S. Alam and R. C. Sickles, "Time series analysis of deregulatory dynamics and technical efficiency: the case of the US airline industry," International Economic Review, vol. 41, no. 1, pp. 203-218, 2000.

[36] W. Y. Wu and Y. K. Liao, "A balanced scorecard envelopment approach to assess airlines' performance," Industrial Management \& Data Systems, vol. 114, no. 1, pp. 123-143, 2014.

[37] M. D. Fethi, P. M. Jackson, and T. G. Weyman-Jones, "Measuring the efficiency of european airlines: an application of DEA and tobit analysis," Engneering, 2000.

[38] C. A. Scheraga, "The relationship between operational efficiency and customer service: a global study of thirty-eight large international airlines," Transportation Journal, vol. 43, no. 3, pp. 48-58, 2004.

[39] M. R. Greer, "Are the discount airlines actually more efficient than the legacy carriers?: a data envelopment analysis," International Journal of Transport Economics, vol. 33, no. 1, pp. 37-55, 2006.

[40] D. Bhadra, "Race to the bottom or swimming upstream: performance analysis of US airlines," Journal of Air Transport Management, vol. 15, no. 5, pp. 227-235, 2009.

[41] K. Cheng, Z.-H. Lee, and H. Shomali, "Airline firm boundary and ticket distribution in electronic markets," International Journal of Production Economics, vol. 137, no. 1, pp. 137-144, 2012.

[42] Y. Wu, C. He, and X. Cao, "The impact of environmental variables on the efficiency of Chinese and other non-Chinese airlines," Journal of Air Transport Management, vol. 29, no. 2, pp. 35-38, 2013.

[43] Q. Cui and Y. Li, "The change trend and influencing factors of civil aviation safety efficiency: the case of Chinese airline companies," Safety Science, vol. 75, pp. 56-63, 2015.

[44] H. Saranga and R. Nagpal, "Drivers of operational efficiency and its impact on market performance in the Indian airline industry," Journal of Air Transport Management, vol. 53, pp. 165-176, 2016.
[45] J.-L. Hu, Y. Li, and H.-J. Tung, "Operational efficiency of ASEAN airlines: based on DEA and bootstrapping approaches," Management Decision, vol. 55, no. 5, pp. 957-986, 2017.

[46] Y. H. Ling, T. Kokkiang, B. Gharleghi, and B. C. Y. Fah, "Productivity and efficiency modeling amongst ASEAN-5 airline industries," International Journal of Advanced and Applied Sciences, vol. 5, no. 8, pp. 47-57, 2018.

[47] A. Arjomandi and J. H. Seufert, "An evaluation of the world's major airlines' technical and environmental performance," Economic Modelling, vol. 41, no. 41, pp. 133-144, 2014.

[48] K. Choi, "Multi-period efficiency and productivity changes in US domestic airlines," Journal of Air Transport Management, vol. 59, pp. 18-25, 2017.

[49] B. L. Lee and A. C. Worthington, "Technical efficiency of mainstream airlines and low-cost carriers: new evidence using bootstrap data envelopment analysis truncated regression," Journal of Air Transport Management, vol. 38, no. 3, pp. 15-20, 2014.

[50] Z. Chen, P. Wanke, J. J. M. Antunes, and N. Zhang, "Chinese airline efficiency under $\mathrm{CO}_{2}$ emissions and flight delays: a stochastic network DEA model," Energy Economics, vol. 68, pp. 89-108, 2017.

[51] M. D. Fethi, P. M. Jackson, and T. G. Weyman-Jones, "European airlines: a stochastic DEA study of efficiency with market liberalisation," in Proceedings of the Efficiency and Productivity Research Unit, University of Leicester, Leicester, UK, 2001.

[52] M. Duygun, D. Prior, M. Shaban, and E. Tortosa-Ausina, "Disentangling the European airlines efficiency puzzle: a network data envelopment analysis approach," Omega, vol. 60 , pp. 2-14, 2016.

[53] M. C. N. Gramani, "Efficiency decomposition approach: a cross-country airline analysis," Expert Systems with Applications, vol. 39, no. 5, pp. 5815-5819, 2012.

[54] C.-Y. Lee and A. L. Johnson, "Two-dimensional efficiency decomposition to measure the demand effect in productivity analysis," European Journal of Operational Research, vol. 216, no. 3, pp. 584-593, 2012.

[55] W. M. Lu, W. K. Wang, S. W. Hung, and E. T. Lu, "The effects of corporate governance on airline performance: production and marketing efficiency perspectives," Transportation Research Part E: Logistics and Transportation Review, vol. 48, no. 2, pp. 529-544, 2012.

[56] S. Mallikarjun, "Efficiency of US airlines: a strategic operating model," Journal of Air Transport Management, vol. 43, pp. 46-56, 2015.

[57] J. Zhu, "Airlines performance via two-stage network DEA approach," Journal of Centrum Cathedra, vol. 4, no. 2, pp. 260-269, 2011.

[58] Q. Cui, Y. Li, C.-l. Yu, and Y.-M. Wei, "Evaluating energy efficiency for airlines: an application of virtual frontier dynamic slacks based measure," Energy, vol. 113, pp. 12311240, 2016.

[59] H. Omrani and E. Soltanzadeh, "Dynamic DEA models with network structure: an application for Iranian airlines," Journal of Air Transport Management, vol. 57, pp. 52-61, 2016.

[60] J. K. Sengupta, "A dynamic efficiency model using data envelopment analysis," International Journal of Production Economics, vol. 62, no. 3, pp. 209-218, 1999.

[61] P. Wanke and C. P. Barros, "Efficiency in Latin American airlines: a two-stage approach combining virtual. frontier 
dynamic DEA and simplex regression," Journal of Air Transport Management, vol. 54, pp. 93-103, 2016.

[62] Q. Cui and Y. Li, "Evaluating energy efficiency for airlines: an application of VFB-DEA," Journal of Air Transport Management, vol. 44-45, pp. 34-41, 2015.

[63] A. T. Kottas and M. A. Madas, "Comparative efficiency analysis of major international airlines using data envelopment analysis: exploring effects of alliance membership and other operational efficiency determinants," Journal of Air Transport Management, vol. 70, pp. 1-17, 2018.

[64] E. Soltanzadeh and H. Omrani, "Dynamic network data envelopment analysis model with fuzzy inputs and outputs: an application for Iranian airlines," Applied Soft Computing, vol. 63, pp. 268-288, 2018.

[65] P. Ouellette, P. Petit, L. P. Tessier-Parent, and S. Vigeantcd, "Introducing regulation in the measurement of efficiency, with an application to the Canadian air carriers industry," European Journal of Operational Research, vol. 200, no. 1, pp. 216-226, 2010.

[66] K. Choi, D. Lee, and D. L. Olson, "Service quality and productivity in the US airline industry: a service qualityadjusted DEA model," Service Business, vol. 9, no. 1, pp. 137-160, 2015.

[67] C. P. Barros, Q. B. Liang, and N. Peypoch, "The technical efficiency of US Airlines," Transportation Research Part A: Policy and Practice, vol. 50, pp. 139-148, 2013.

[68] H. Geng, H. Jia, and J. Chen, "A significant efficiency evaluation method based on DEA for airline carbon emission reduction," in Proceedings of the 2013 Chinese Automation Congress, pp. 212-215, IEEE, Changsha, China, November 2013.

[69] Q. Cui and Y. Li, "Airline energy efficiency measures considering carbon abatement: a new strategic framework," Transportation Research Part D: Transport and Environment, vol. 49, pp. 246-258, 2016.

[70] M. Tavassoli, G. R. Faramarzi, and R. F. Saen, "Efficiency and effectiveness in airline performance using a SBM-NDEA model in the presence of shared input," Journal of Air Transport Management, vol. 34, no. 1, pp. 146-153, 2014.

[71] Y.-T. Chang, H.-s. Park, J.-b. Jeong, and J.-w. Lee, "Evaluating economic and environmental efficiency of global airlines: a SBM-DEA approach," Transportation Research Part D: Transport and Environment, vol. 27, no. 1, pp. 46-50, 2014.

[72] Y.-C. Chang and M.-M. Yu, "Measuring production and consumption efficiencies using the slack-based measure network data envelopment analysis approach: the case of low-cost carriers," Journal of Advanced Transportation, vol. 48, no. 1, pp. 15-31, 2014.

[73] S. Lozano and E. Gutiérrez, "A slacks-based network DEA efficiency analysis of European airlines," Transportation Planning and Technology, vol. 37, no. 7, pp. 623-637, 2014.

[74] Y. Li, Y.-Z. Wang, and Q. Cui, "Evaluating airline efficiency: an application of virtual frontier network SBM," Transportation Research Part E: Logistics and Transportation Review, vol. 81, pp. 1-17, 2015.

[75] H.-W. Chou, C.-Y. Lee, H.-K. Chen, and M.-Y. Tsai, "Evaluating airlines with slack-based measures and metafrontiers," Journal of Advanced Transportation, vol. 50, no. 6, pp. 1061-1089, 2016.

[76] Y. Li, Y. Z. Wang, and Q. Cui, "Energy efficiency measures for airlines: an application of virtual frontier dynamic range adjusted measure," Journal of Renewable and Sustainable Energy, vol. 8, no. 1, pp. 207-232, 2016.
[77] Y. Li, Y.-z. Wang, and Q. Cui, "Has airline efficiency affected by the inclusion of aviation into European union Emission trading scheme? evidences from 22 airlines during 2008-2012," Energy, vol. 96, pp. 8-22, 2016b.

[78] M. Tavassoli, T. Badizadeh, and R. F. Saen, "Performance assessment of airlines using range-adjusted measure, strong complementary slackness condition, and discriminant analysis," Journal of Air Transport Management, vol. 54, pp. 42-46, 2016.

[79] M. M. Yu, L. H. Chen, and B. Hsiao, "A fixed cost allocation based on the two-stage network data envelopment approach," Journal of Business Research, vol. 69, no. 5, pp. 1817-1822, 2016.

[80] X. Xu and Q. Cui, "Evaluating airline energy efficiency: an integrated approach with network epsilon-based measure and network slacks-based measure," Energy, vol. 122, pp. 274-286, 2017.

[81] Q. Cui and Y. Li, "Airline efficiency measures using a dynamic epsilon-based measure model," Transportation Research Part A: Policy and Practice, vol. 100, pp. 121-134, 2017.

[82] J. Zhang, H. Fang, H. Wang, M. Jia, J. Wu, and S. Fang, "Energy efficiency of airlines and its influencing factors: a comparison between China and the United States," Resources Conservation and Recycling, vol. 125, pp. 1-8, 2017.

[83] M. M. Yu, L. H. Chen, and C. Hui, "The effects of alliances and size on airlines' dynamic operational performance," Transportation Research Part A Policy and Practice, vol. 106, pp. 197-214, 2017.

[84] C. N. Wang, D. C. Dang, N. V. Van Thanh, and T. T. Tran, "Grey model and DEA to form virtual strategic alliance: the application for ASEAN aviation industry," International Journal of Advanced and Applied Sciences, vol. 5, no. 6, pp. 25-34, 2018.

[85] Q. Cui and Y. Li, "CNG2020 strategy and airline efficiency: a network epsilon-based measure with managerial disposability," International Journal of Sustainable Transportation, vol. 12, no. 5, pp. 313-323, 2018.

[86] K. Tone and M. Tsutsui, "An epsilon-based measure of efficiency in DEA-a third pole of technical efficiency," European Journal of Operational Research, vol. 207, no. 3, pp. 1554-1563, 2010b.

[87] Q. Cui, “Airline energy efficiency measures using a network range-adjusted measure with unified natural and managerial disposability," Energy Efficiency, vol. 13, no. 6, pp. 1195-1211, 2020.

[88] Y. Li and Q. Cui, "Airline energy efficiency measures using the virtual frontier network RAM with weak disposability," Transportation Planning and Technology, vol. 40, no. 4, pp. 479-504, 2017a.

[89] Q. Cui, "Will airlines' pollution abatement costs be affected by CNG2020 strategy? an analysis through a network environmental production function," Transportation Research Part D: Transport and Environment, vol. 57, pp. 141-154, 2017.

[90] Y. Li and Q. Cui, "Carbon neutral growth from 2020 strategy and airline environmental inefficiency: a network range adjusted environmental data envelopment analysis," Applied Energy, vol. 199, pp. 13-24, 2017.

[91] Y. Li and Q. Cui, "Airline efficiency with optimal employee allocation: an input-shared network range adjusted measure," Journal of Air Transport Management, vol. 73, pp. 150-162, 2018. 
[92] R. Färe and S. Grosskopf, "Productivity and intermediate products: a frontier approach," Economics Letters, vol. 50, no. 1, pp. 65-70, 1996.

[93] K. Tone and M. Tsutsui, "Dynamic DEA: a slacks-based measure approach,” Omega, vol. 38, no. 3-4, pp. 145-156, 2010.

[94] C. Kao and S.-N. Hwang, "Efficiency measurement for network systems: IT impact on firm performance," Decision Support Systems, vol. 48, no. 3, pp. 437-446, 2010.

[95] P.-C. Chen, "Measurement of technical efficiency in farrowto-finish swine production using multi-activity network data envelopment analysis: evidence from Taiwan," Journal of Productivity Analysis, vol. 38, no. 3, pp. 319-331, 2012.

[96] W. K. Wang, F. Lin, I. W. K. Ting, L. K. Qian, W. M. Lu, and T. Y. Chiu, "Does asset-light strategy contribute to the dynamic efficiency of global airlines?" Journal of Air Transport Management, vol. 62, pp. 99-108, 2017.

[97] Q. Cui, Y.-M. Wei, and Y. Li, "Exploring the impacts of the EU ETS emission limits on airline performance via the dynamic environmental DEA approach," Applied Energy, vol. 183, pp. 984-994, 2016.

[98] Q. Cui and Y. Li, "Airline efficiency measures under CNG2020 strategy: an application of a dynamic by-production model," Transportation Research Part A: Policy and Practice, vol. 106, pp. 130-143, 2017.

[99] Q. Cui and Y. Li, "Airline dynamic efficiency measures with a dynamic RAM with unified natural \& managerial disposability," Energy Economics, vol. 9, no. 75, pp. 534-546, 2018.

[100] Q. Cui and Y. Li, "Will airline efficiency be affected by "carbon neutral growth from 2020" strategy? Evidences from 29 international airlines," Journal of Cleaner Production, vol. 164, pp. 1289-1300, 2017.

[101] Q. Cui, Y. Li, and J.-1. Lin, "Pollution abatement costs change decomposition for airlines: an analysis from a dynamic perspective," Transportation Research Part A: Policy and Practice, vol. 111, pp. 96-107, 2018.

[102] Y. Li and Q. Cui, "Investigating the role of cooperation in the GHG abatement costs of airlines under CNG2020 strategy via a DEA cross PAC model," Energy, vol. 161, pp. 725-736, 2018.

[103] Q. Cui, Y. M. Wei, C. L. Yu, and Y. Li, "Measuring the energy efficiency for airlines under the pressure of being included into the EU ETS," Journal of Advanced Transportation, vol. 50, no. 8, pp. 1630-1649, 2016. 